\title{
METHOTREXATE USE IS SAFE IN CHILDREN WITH ACUTE LYMPHOBLASTIC LEUKEMIA
}

\author{
Febriansyah Nur Utomo ${ }^{1}$, Yulistiani ${ }^{2}$, Nun Zairina ${ }^{3}, B^{2}$ ambang Permono ${ }^{4}$ \\ ${ }^{1,2}$ Department of Clinical Pharmacy, Faculty of Pharmacy, Airlangga University, ${ }^{3}$ Clinical Pharmacy, Dr. Soetomo \\ Hospital, Surabaya, ${ }^{4}$ Hemato-Oncology Division, Department of Pediatrics, Faculty of Medicine, Airlangga University, \\ Dr. Soetomo Hospital, Surabaya
}

\begin{abstract}
ABSTRAK
Pemantauan kadar metotreksat tidak hanya ditujukan untuk memantau efektivitas, namun juga keamanan pemberian metotreksat dosis tinggi karena penggunaan metotreksat dosis tinggi adalah salah satu masalah yang terkait dengan toksisitas pada berbagai organ. Pada penggunaan metotreksat dosis tinggi, pengukuran metotreksat penting untuk mengidentifikasi pasien dengan risiko toksisitas tinggi, terutama nefrotoksisitas, dan juga untuk pedoman pemberian dosis untuk terapi leucovorin. Tujuan dari penelitian ini adalah untuk menganalisis keamanan metotreksat dosis tinggi terhadap fungsi ginjal selama fase konsolidasi kemoterapi pada anak-anak dengan leukemia limfoblastik akut. Penelitian ini adalah penelitian prospektif longitudinal yang dilakukan untuk menentukan profil keselamatan metotreksat dosis tinggi pada fungsi ginjal selama fase konsolidasi kemoterapi pada anak-anak dengan leukemia limfoblastik akut. Pasien yang memenuhi kriteria inklusi diberi metotreksat dosis tinggi sesuai dengan protokol kemoterapi LLA Indonesia 2013. Pengukuran kadar metotreksat dan fungsi ginjal dilakukan 3 kali pada setiap siklus fase konsolidasi kemoterapi. Pengukuran dilakukan pada 0, 24 dan 48 jam setelah tetes pertama metotreksat dosis tinggi. Penelitian ini telah dikaji oleh Komite Etika Rumah Sakit Dr. Soetomo Surabaya. Terdapat 12 pasien yang memenuhi kriteria inklusi dan 6 pasien di antaranya telah menyelesaikan fase konsolidasi kemoterapi sepenuhnya. Tidak ada perubahan fungsi ginjal yang signifikan setelah pemberian metotreksat dosis tinggi dibandingkan dengan baseline $(p>0,05)$ dan tidak ada korelasi yang signifikan antara kadar serum metotreksat versus klirens kreatinin. Sebagai simpulan, metotreksat aman digunakan pada anak-anak dengan leukemia limfoblastik akut. (FMI 2017;53:144-151)
\end{abstract}

Kata kunci: metotreksat dosis tinggi, fungsi ginjal, leukemia limfoblastik akut, fase konsolidasi

\begin{abstract}
Monitoring level of methotrexate is not only aimed at monitoring effectiveness, but also safety aspects of the administration of highdose methotrexate because the use of high-dose methotrexate is one of the problems associated with toxicity in various organs. In the use of high-dose methotrexate, measurement of methotrexate is important to identify patients with a high risk of toxicity, particularly nephrotoxicity as well as for dosing guidelines for leucovorin therapy. The aim of this study was to analyze the safety of high-dose methotrexate on kidney function during chemotherapy consolidation phase in children with acute lymphoblastic leukemia. This was a longitudinal, observational prospective study conducted to determine the safety profile of high-dose methotrexate on kidney function during chemotherapy consolidation phase in children with acute lymphoblastic leukemia. Patients who met the inclusion criteria were given high-dose methotrexate according to the 2013 Indonesian ALL Chemotherapy Protocol. Measurement of methotrexate level and kidney function was done 3 times on each cycle of chemotherapy consolidation phase. Measurements were made on the 0, 24 and 48 hours after the first drop of high-dose methotrexate. This study had been reviewed by Ethics Committee of Dr. Soetomo Hospital Surabaya. There were 12 patients who met inclusion criteria and 6 patients among them had finished their chemotherapy consolidation phase completely. There was no significant change in kidney function after the administration of highdose methotrexate compared to baseline $(p>0.05)$ and there was no significant correlation between serum level of methotrexate versus creatinine clearance. In conclusion, methotrexate was safe to use in children with acute lymphoblastic leukemia. (FMI 2017;53:144-151)
\end{abstract}

Keywords: High-dose Methotrexate, Kidney Function, Acute Lymphoblastic Leukemia, Consolidation Phase

Correspondence: Febriansyah Nur Utomo, Delta Sari Indah D/321 Waru Sidoarjo. Email:

febriansyah.utomo@gmail.com

\section{INTRODUCTION}

Acute Lymphoblastic Leukemia (ALL) is an organ malignancy that produces blood components, making the bone narrow being dominated by lymphocytic malignant clones, and the spread of malignant cells to blood and all organs in the body occurs (Kliegmann et al 2016). The 2013 Indonesian ALL Chemotherapy Protocol stated there were 3 three stages of ALL treatment, i.e. induction phase, injection/ intensification phase, and maintenance phase.

The consolidation phase is the second stage of ALL treatment, focusing on prophylactic (prevention) thera- 
py of leukemic progressiveness up to the central nervous system (CNS) with cell blast count of $<5 \%$. The chemotherapy used for central nervous system prophylaxis therapy is repeated intrathecal methotrexate and is combined with intensive high-dose systemic methotrexate chemotherapy (Kliegmann et al 2016, Alldredge et al 2013). The Indonesian ALL Chemo-therapy Protocol stated that in the consolidation phase, a combination of peroral mercaptopurine chemotherapy, intrathecal methotrexate and high dose methotrexate of $1000 \mathrm{mg} / \mathrm{m}^{2}$ was administered intravenously followed by leucovorin rescue therapy.

Methotrexate has a unique characteristic compared to other cancer drugs. It has a very wide dose range $(3 \mathrm{mg}$ - $33600 \mathrm{mg} / \mathrm{m}^{2}$ ). and it is the only cancer drug that requires regular blood levels monitoring. The monitoring of these methotrexate levels is not only aimed as an effective monitoring, but also related to the safety aspect of high doses of methotrexate because its use in high doses is an issue related to its toxicity to various organs. The measurement of methotrexate levels is essential for the use of high-dose methotrexate to identify patients with high risk of toxicity and as a guideline to leucovorin therapy dosage (Borsi et al 1987, Lennard 1999).

This study aimed to analyze the safety of methotrexate in pediatric patients with ALL, focused on monitoring the side effects of methotrexate nephrotoxicity and drug levels in the blood. The measurement of methotrexate levels made on the 24 and 48 hours was calculated since the first droplet of methotrexate, and the change of patients' renal function was measured after high doses of methotrexate compared with baseline.

\section{MATERIALS AND METHODS}

\section{Patients}

The study sample was all patients diagnosed with acute lymphoblastic leukemia at Pediatric Ward, Dr. Soetomo Hospital, Surabaya, who fulfilled the inclusion criteria. This study used time limited sampling method by taking a number of ALL patients who were treated in pediatric inpatient installation/functional medical staff of Pediatric Ward, Dr. Soetomo Hospital, Surabaya, fulfilling the inclusion criteria in the period from June to August 2016. The patient inclusion criteria in this study included male/female patients aged 0-18 years, patients diagnosed with acute lymphoblastic leukemia who were in consolidation phase therapy and received $1 \mathrm{~g} / \mathrm{m}^{2}$ high dose methotrexate intravenously based on the ALL Chemotherapy Protocol in Indonesia, as well as the parents of patients who were willing to sign informed consent.
Exclusion criteria in this study were patients with kidney disease or patients with creatinine clearance $<15$ $\mathrm{ml} / \mathrm{min}$.

\section{High dose methotrexate regimens}

All patients in this study received $1000 \mathrm{mg} / \mathrm{m}^{2}$ methotrexate therapy in accordance with ALL Indonesian Chemotherapy Protocol in 2013. First, patients received $12 \mathrm{mg}$ intrathecal methotrexate thera-py. Secondly, the patient received hydration therapy and pre-methotrexate urine alkalinization of $5 \mathrm{ml} 8.4 \%$ sodium bicarbonate diluted in $250 \mathrm{ml} \mathrm{D} 51 / 2$ saline infusion and administered for 4 hours. The high-dose metho-trexate was dissolved into $1000 \mathrm{ml}$ saline infusion and administered for 24 hours intravenously. After administration of high doses of methotrexate, patients also received hydration therapy and urine alkalinization comp-rising $20 \mathrm{ml} \mathrm{8.4 \%} \mathrm{sodium} \mathrm{bicarbonate} \mathrm{diluted} \mathrm{into} 1000 \mathrm{ml}$ of D5 $1 / 2$ saline infusion administered for 24 hours. Leucovorin rescue therapy was administered at a dose of 15 $\mathrm{mg} / \mathrm{m}^{2}$ after the patient finished undergoing post-methotrexate hydration.

\section{Measurement of methotrexate levels in serum and creatinine serum}

Measurements of methotrexate levels in patients' blood and kidney function were performed 3 times in each cycle of the consolidation phase chemotherapy. Measurements were performed at hours 0,24 and 48 after the first droplet of high doses of methotrexate.

\section{Statistical analysis}

Analysis of changes in patients' renal function was done by paired T-test. The association analysis of blood methotrexate levels with creatinine clearance was performed by Pearson correlation test. The result of statistical test was significant if $\mathrm{p}<0,05$ with $95 \%$ confidence interval.

\section{RESULTS}

There were 14 ALL patients undergoing consolidation phase chemotherapy and all met the inclusion criteria. Patients who received complete consolidation phase chemotherapy from the first to the third cycle were 10 out of 14 persons. Thus, in this study, the total sample obtained were 36 units which would be analyzed statistically.

Table 2 shows the serum creatinine serum profile of 14 ALL patients receiving high-dose methotrexate therapy. 
Table 1. Initial characteristics of the patients

\begin{tabular}{llcc}
\hline \multicolumn{1}{c}{ Patients' Characteristics } & $\begin{array}{c}\text { Number of Patients } \\
(\mathrm{n}=14)\end{array}$ & $\begin{array}{c}\text { Percentage } \\
(\%)\end{array}$ \\
\hline Gender & Male & 9 & 64 \\
Age Range & Female & 5 & 36 \\
& $0-9$ years old & 9 & 64 \\
BMP Morphology Results & L1 & 5 & 36 \\
Risk Groups & Normal (SR) & 12 & 100 \\
& High (HR) & 8 & 57 \\
Creatinine Clearance & $>100 \mathrm{ml} / \mathrm{min} / 1.73 \mathrm{~m}^{2}$ & 6 & 43 \\
Baseline & & 12 & 100 \\
Creatinine Serum & $0.1-1 \mathrm{mg} / \mathrm{dl}$ & & 100 \\
Baseline & & 12 & 0 \\
Accepted Chemotherapy & I & & 0 \\
Cycles (36 sample units) & II & 0 & 14.29 \\
& III & 0 & 7.14 \\
& I + II & 2 & 0 \\
& I + III & 1 & 7.14 \\
& II + III & 0 & 71.43 \\
\hline
\end{tabular}

Table 2. Creatinine serum profile of ALL patients in consolidation phase

\begin{tabular}{cccc}
\hline Hours & $\begin{array}{c}\text { Average SCr Cycle I } \pm \\
\text { SD (Range) }\end{array}$ & $\begin{array}{c}\text { Average SCr Cycle II } \pm \\
\text { SD (Range) }\end{array}$ & $\begin{array}{c}\text { Average SCr Cycle III } \pm \text { SD } \\
\text { (Range) }\end{array}$ \\
\hline 0 & $0,39 \pm 0,12 \mathrm{mg} / \mathrm{dl}$ & $0,41 \pm 0,17 \mathrm{mg} / \mathrm{dl}$ & $0,38 \pm 0,11 \mathrm{mg} / \mathrm{dl}$ \\
& $(0,26-0,56)$ & $(0,15-0,79)$ & $(0,19-0,54)$ \\
24 & $0,42 \pm 0,17 \mathrm{mg} / \mathrm{dl}$ & $0,36 \pm 0,14 \mathrm{mg} / \mathrm{dl}$ & $0,36 \pm 0,14 \mathrm{mg} / \mathrm{dl}$ \\
& $(0,18-0,73)$ & $(0,09-0,55)$ & $(0,14-0,60)$ \\
48 & $0,42 \pm 0,16 \mathrm{mg} / \mathrm{dl}$ & $0,33 \pm 0,12 \mathrm{mg} / \mathrm{dl}$ & $0,38 \pm 0,13 \mathrm{mg} / \mathrm{dl}$ \\
& $(0,23-0,69)$ & $(0,15-0,49)$ & $(0,19-0,52)$ \\
\hline
\end{tabular}

Table 3. Creatinine clinical profile of ALL patients in the consolidation phase

\begin{tabular}{|c|c|c|c|c|c|c|c|c|c|}
\hline \multirow{4}{*}{$\begin{array}{c}\mathrm{CrCl} \\
(\mathrm{ml} / \mathrm{min} / 1.73 \\
\left.\mathrm{m}^{2}\right)\end{array}$} & \multicolumn{9}{|c|}{ Number of Patients } \\
\hline & \multicolumn{3}{|c|}{ Cycle 1} & \multicolumn{3}{|c|}{ Cycle 2} & \multicolumn{3}{|c|}{ Cycle 3} \\
\hline & Hour & Hour & Hour & Hour & Hour & Hour & Hour & Hour & Hour \\
\hline & 0 & 24 & 48 & 0 & 24 & 48 & 0 & 24 & 48 \\
\hline$\geq 100$ & 11 & 11 & 10 & 11 & 12 & 12 & 13 & 13 & 13 \\
\hline $99-70$ & 0 & 0 & 1 & 1 & 0 & 0 & 0 & 0 & 0 \\
\hline$<70$ & 0 & 0 & 0 & 0 & 0 & 0 & 0 & 0 & 0 \\
\hline
\end{tabular}

Note: Creatinine clearance was calculated using the Schwartz method $=($ Body length $(\mathrm{cm}) \mathrm{x} \mathrm{k}) /$ serum creatinine $(\mathrm{mg} / \mathrm{dl})$

Serum creatinine levels measured at hours 0,24 , and 48 were calculated from the first droplet of methotrexate in each chemotherapy cycle during the consolidation phase. The results of statistical tests conducted by paired T-test showed no statistically significant change in patients' creatinine serum compared with baseline, the hour 0 point in cycle $1(p>0.05)$. Based on the obtained serum creatinine data, the patients' creatinine clearance may be calculated using the Schwartz formula shown in
Table 3. Methotrexate levels in the patients' blood were obtained from patient blood sampling at hours 0,24 and 48, calculated from the first droplet of high doses of methotrexate in each cycle of the consolidation phase chemotherapy. Table 4 shows the distribution profile of methotrexate levels in patients' blood which received high-dose methotrexate therapy. The data on methotrexate level in blood were shown regardless of the cycle. 
Table 4. Distribution profile of methotrexate levels in the patients' blood

\begin{tabular}{|c|c|c|c|c|c|c|c|c|c|}
\hline \multirow{3}{*}{$\begin{array}{c}\text { Patients' } \\
\text { Initial }\end{array}$} & \multicolumn{9}{|c|}{ Methotrexate in Patients' Blood (ng/ml) } \\
\hline & \multicolumn{3}{|c|}{ Cycle 1} & \multicolumn{3}{|c|}{ Cycle 2} & \multicolumn{3}{|c|}{ Cycle 3} \\
\hline & $\begin{array}{c}\text { Hour } \\
0\end{array}$ & $\begin{array}{c}\text { Hour } \\
24\end{array}$ & $\begin{array}{c}\text { Hour } \\
48\end{array}$ & $\begin{array}{c}\text { Hour } \\
0\end{array}$ & $\begin{array}{c}\text { Hour } \\
24\end{array}$ & $\begin{array}{c}\text { Hour } \\
48\end{array}$ & $\begin{array}{c}\text { Hour } \\
0\end{array}$ & $\begin{array}{c}\text { Hour } \\
24\end{array}$ & $\begin{array}{c}\text { Hour } \\
48\end{array}$ \\
\hline DI & - & - & - & - & - & - & 36.32 & 55.47 & 51.03 \\
\hline VC & - & - & - & - & - & - & 14.03 & 16.67 & 14.42 \\
\hline AS & - & - & - & 25.75 & 23.35 & 21.15 & 29.55 & 21.23 & 21.28 \\
\hline GS & 13.81 & 14.63 & 10.73 & 11.40 & 12.21 & 12.15 & 5.57 & 13.97 & 12.88 \\
\hline AM & 19.99 & 28.13 & 18.36 & 15.18 & 12.62 & 9.79 & 10.65 & 19.14 & 2.00 \\
\hline AA & 14.17 & 10.77 & 10.91 & 10.06 & 12.18 & 10.83 & 40.85 & 38.52 & 31.59 \\
\hline AI & 16.17 & 14.64 & 16.17 & 30.69 & 25.94 & 25.74 & 14.68 & 14.91 & 13.44 \\
\hline MK & 23.92 & 18.16 & 12.26 & 13.71 & 14.94 & 14.22 & 23.45 & 23.06 & 20.54 \\
\hline MH & 13.29 & 11.49 & 11.43 & 22.80 & 24.1 & 23.51 & 13.02 & 17.25 & 14.07 \\
\hline BI & 20.98 & 30.35 & 19.37 & 25.43 & 16.85 & 15.74 & 20.84 & 22.53 & 18.83 \\
\hline $\mathrm{RN}$ & 13.49 & 13.10 & 12.78 & 12.64 & 13.72 & 11.34 & 19.17 & 27.27 & 19.34 \\
\hline FR & 18.44 & 26.12 & 16.43 & 78.30 & 66.56 & 46.85 & + & + & + \\
\hline ST & 177.32 & 282.01 & 172.12 & 243.44 & 316.56 & 231.14 & 244.41 & 234.23 & 215.84 \\
\hline LG & 162.70 & 230.36 & 175.12 & 180.86 & 161.47 & 136.676 & 180.97 & 300.27 & 196.14 \\
\hline $\begin{array}{l}\text { Average } \pm \\
\text { SD }\end{array}$ & $\begin{array}{c}44.94 \pm \\
62.02\end{array}$ & $\begin{array}{c}61.80 \pm \\
97.03\end{array}$ & $\begin{array}{c}43.30 \pm \\
64.66\end{array}$ & $\begin{array}{c}55.85 \pm \\
76.42\end{array}$ & $\begin{array}{c}58.38 \pm \\
91.84\end{array}$ & $\begin{array}{c}46.60 \pm \\
67.99\end{array}$ & $\begin{array}{c}50.27 \pm \\
73.92\end{array}$ & $\begin{array}{c}61.88 \pm \\
92.82\end{array}$ & $\begin{array}{c}48.57 \pm \\
70.91\end{array}$ \\
\hline Range & $\begin{array}{l}13.29- \\
177.32\end{array}$ & $\begin{array}{l}10.77- \\
282.01\end{array}$ & $\begin{array}{l}10.73- \\
175.12\end{array}$ & $\begin{array}{l}10.06- \\
243.44\end{array}$ & $\begin{array}{l}12.18- \\
316.56\end{array}$ & $\begin{array}{c}9.79- \\
231.14\end{array}$ & $\begin{array}{c}5.57- \\
244.41\end{array}$ & $\begin{array}{l}13.97- \\
300.27\end{array}$ & $\begin{array}{c}2.00- \\
215.84\end{array}$ \\
\hline
\end{tabular}

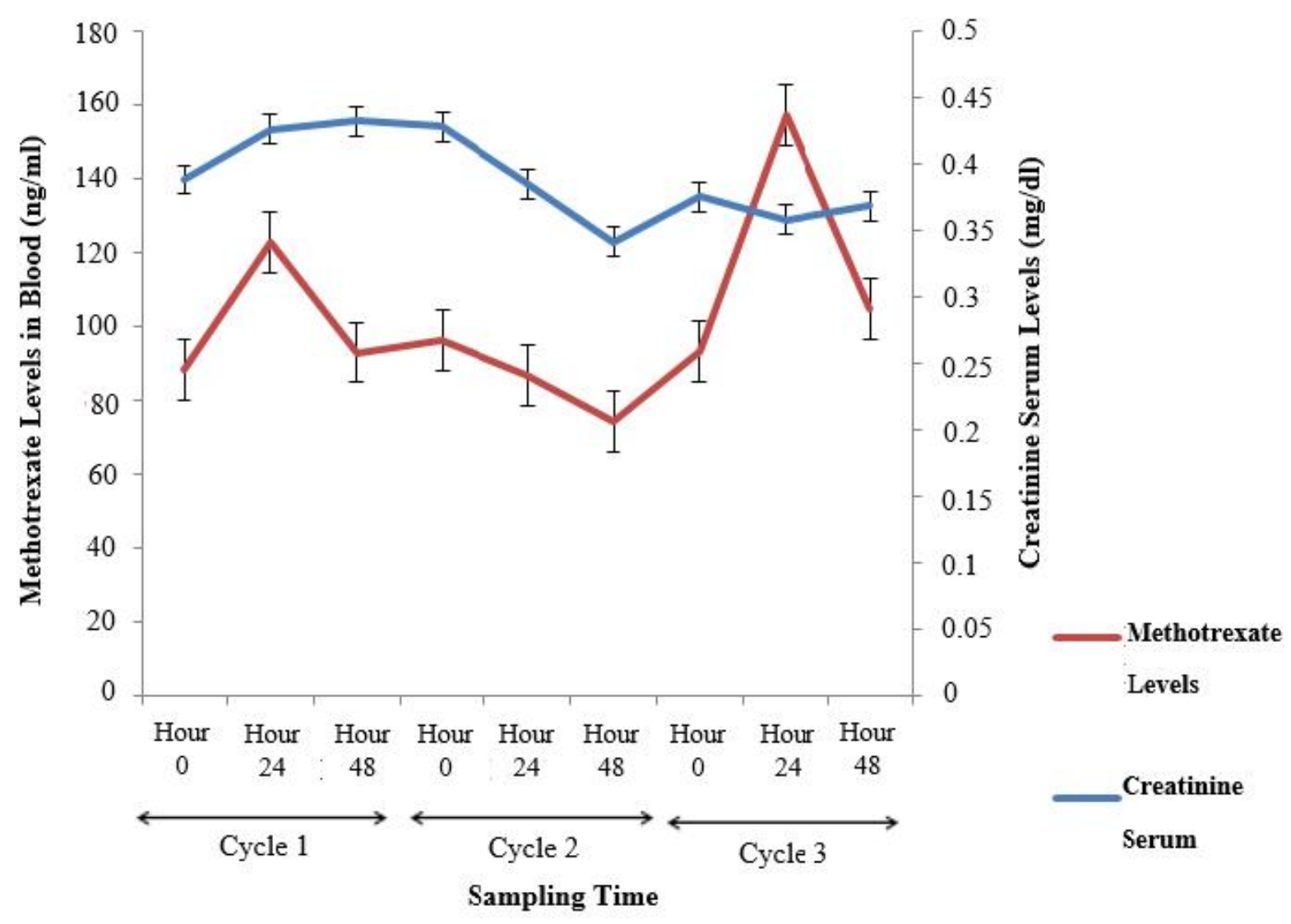

Fig. 1. Methotrexate level profile in serum and the patients' creatinine serum level profile of Acute lymphoblastic leukemia in children with high dose methotrexate therapy of the consolidation phase. 


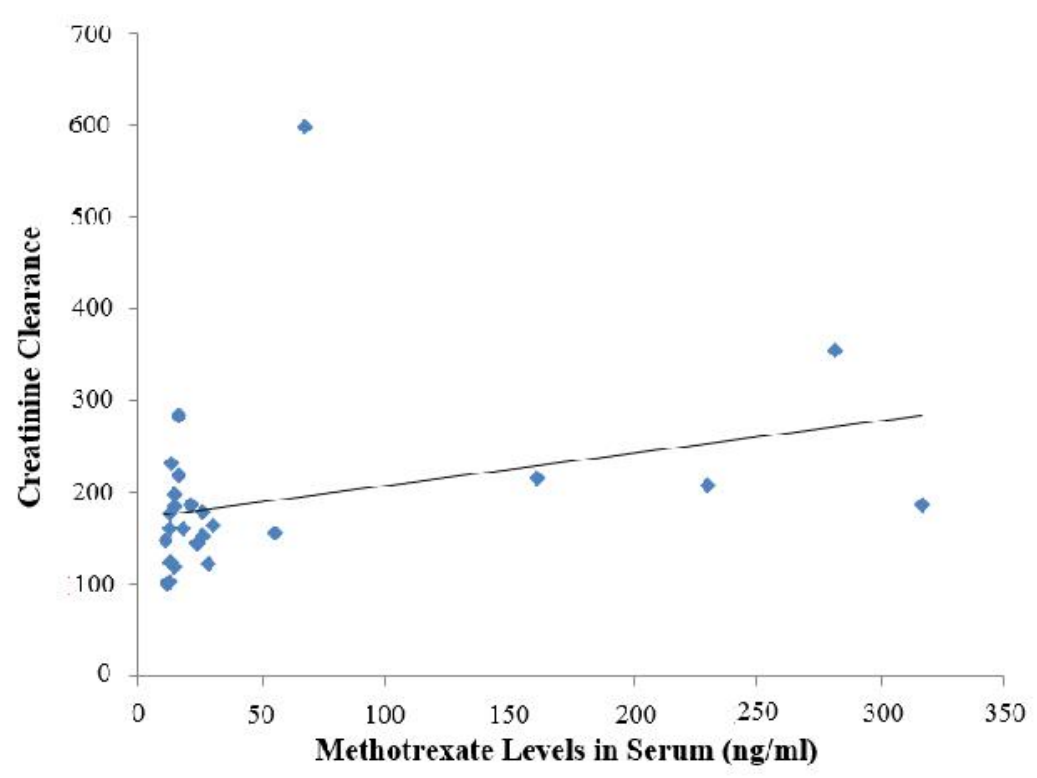

Fig. 2. Correlation profile of methotrexate levels in serum with creatinine clearance at hour 24

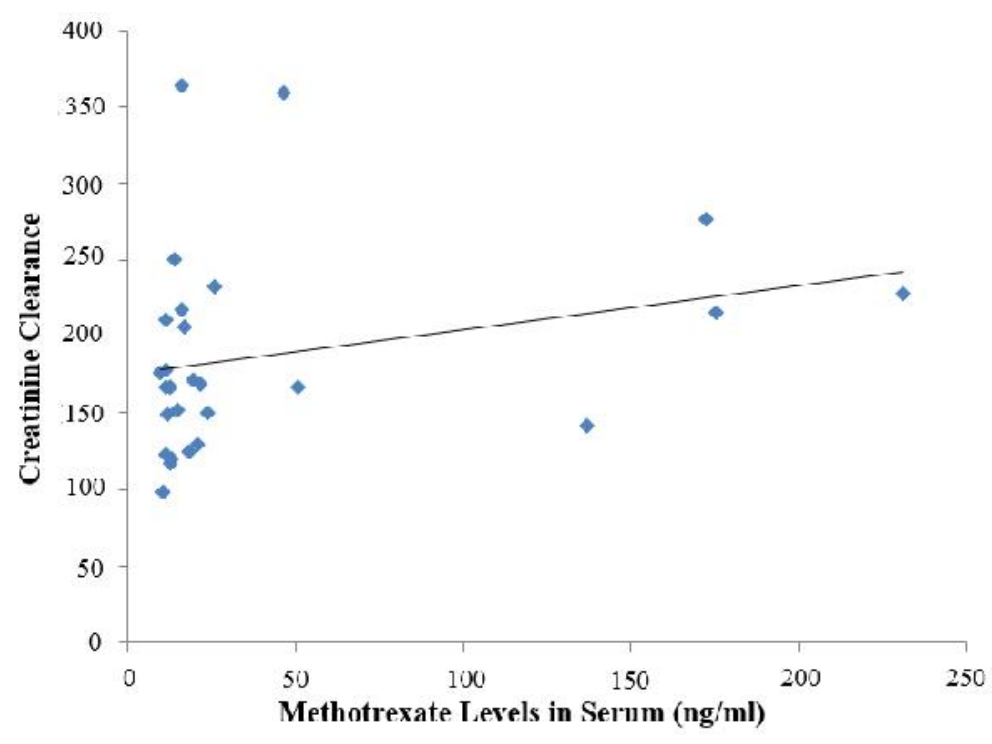

Fig. 3. Correlation profile of methotrexate levels in serum with creatinine clearance at hour 48

Table 5. Correlation analysis results of methotrexate levels in serum with creatinine clearance in patients at hours 24 and 48

\begin{tabular}{|c|c|c|}
\hline & $\begin{array}{l}\text { Creatinine Clearance at } \\
\text { Hour } 24\end{array}$ & $\begin{array}{l}\text { Creatinine Clearance at } \\
\text { Hour } 48\end{array}$ \\
\hline $\begin{array}{l}\text { MTX Level at } \\
\text { Hour 24 }\end{array}$ & $\begin{array}{l}\text { Pearsoncorrelation: } 0.147 \\
p=0.397\end{array}$ & - \\
\hline $\begin{array}{l}\text { MTX Level at } \\
\text { Hour } 48\end{array}$ & - & $\begin{array}{l}\text { Pearsoncorrelation: } 0.157 \\
\mathrm{p}=0.362\end{array}$ \\
\hline
\end{tabular}


After obtaining total sample, only 10 out of 14 patients were observed completely from the beginning to the end. Figure 1 shows the profile of methotrexate levels in those 10 patients' serum. The correlation analysis of methotrexate levels in serum with creatinine clearance at 24 and 48 hours was referred to previous studies. The correlation profile of methotrexate levels in the blood with creatinine clearance at 24 and 48 hours is shown in Figures 2 and 3. Whereas, the correlation analysis results of methotrexate in serum with creatinine clearance at 24 and 48 hours is shown in Table 5. Table 5 shows the results of correlation analysis of methotrexate levels in serum vs creatinine clearance at hours 24 and 48 using the Pearson correlation test method. The results of statistical analysis showed that there was negative correlation between the level of methotrexate in blood and insignificant creatinine clearance. This indicated that if there was the increasing levels of methotrexate in blood, there might be a decrease in creatinine clearance which was not statistically significant.

\section{DISCUSSION}

In this study, we examined the decrease in renal function caused by the use of high-dose methotrexate and the presence of correlation between methotrexate levels at hours 24 and 48 with creatinine clearance. The changes in creatinine serum and creatinine clearance in patients over time were assessed for their significances compared to baseline using paired t-test statistical analysis. The result of statistical analysis showed no significant changes in creatinine serum and creatinine clearance in patients compared with baseline. According to the literatures obtained, the high doses of methotrexate may be safely administered to the patient when combined with hydration, urine alkalinization, and leucovorin rescue.

All ALL patients in Pediatric Ward, Dr Soetomo Hospital, Surabaya, who received high-dose methotrexate therapy always received hydration therapy, urine alkalinization, and leucovorin rescue. These hydration and alkalinization of urine were given with target performance to maintain urine $\mathrm{pH}>7$ because, according to the literature, the solubility of methotrexate in urine depends highly on the urine $\mathrm{pH}$. If the $\mathrm{pH}$ of urine $=7$, the solubility of methotrexate in urine will be higher, thus there will be no precipitation of methotrexate crystals in renal tubules (Jacobs et al 1976). Another literature showed that the urine $\mathrm{pH}$ of patients receiving high-dose methotrexate therapy should be maintained = 6.5 over 24 hours after the provision of high doses of methotrexate (Hallworth \& Capps 1993). Therefore, the treatments of urinary hydration and alkalinization therapy was provided continuously up to 24 hours after the administration of high doses of methotrexate in ALL patients at Pediatric Ward, Dr. Soetomo Hospital, Surabaya. In addition to hydration and alkalinization urine, leucovorin rescue therapy also plays an important role in preventing the occurrence of methotrexate side effects, including nephrotoxicity. Leucovorin will restore reduced folate, which has dropped due to high doses of methotrexate. After conversion into its active metabolite, 5-methyltetrahidrofolate, it will help to reduce toxicity that may result from high doses of methotrexate (Sahnl et al 2009).

The insignificant changes in creatinine serum and creatinine clearance levels in this study were also due to the methotrexate dose administered to pediatric patients with ALL in Indonesia, which was only $1000 \mathrm{mg} / \mathrm{m}^{2}$, relatively smaller than the methotrexate dose administered to pediatric patients with ALL in various cancer treatment centers in the world. This result was similar to the previous study conducted by Hempel et al. in 2003 which compared the effect of several doses of methotrexate $\left(1,5\right.$, and $\left.12 \mathrm{~g} / \mathrm{m}^{2}\right)$ to the patients' renal function. According to the results of the study, in the group of patients who received $1 \mathrm{~g} / \mathrm{m}^{2}$ dose methotrexate, there was no significant GFR decrease compared to baseline GFR value (Hempel et al 2003).

The results of this study indicated that at the point of hour 0 , there has already been measurable levels of methotrexate in the patient's blood. This was because the point 0 in this study was done 2 hours after the patients received intrathecal methotrexate. Bleyer and Dedrick's study in 1978 showed that intrathecal methorexate administration would provide peak plasma levels 3 to 12 hours after injection and would fall with a halflife of 5.5 to 24 hours. The pharmacokinetic analysis of the study showed that the predominant way of transferring methotrexate levels from cerebrospinal fluid to the systemic circulation was by absorbing the mass stream containing methotrexate from the cerebro-spinal fluid. This was the result of interaction of convec-tive transport and diffusion between cerebrospinal liquids and brain extracellular fluid (Bleyer \& Dedrick 1978). The measured methotrexate levels in this study subjects were much lower than the study conducted by Joannon et al. in 2004 that used the same dose of methotrexate, $1000 \mathrm{mg} / \mathrm{m}^{2}$.

The disposition of methotrexate in body has high interindividual variability. The specific characteristics of each patient which become important parts of high variability in this methotrexate disposition are kidney and liver function, patient age, and other factors, such as 
emesis and drugs used along with high dose of methotrexate (Odoul et al 1999). The high variability of methotrexate disposition may also be observed in this study result. The number of measured methotrexate levels in one patient compared to the other were not the same, so it is necessary to estimate the parameters of methotrexate pharmacokinetics individually in ALL pediatric patients in Indonesia to reduce the amount of blood taking for monitoring the levels of methotrexate in blood.

Other assumption regarding to kinetic variability after high dose of methotrexate administration may also be due to the function of multispecialific organic anionic transporters in canaluli, also known as Adenosine triphosphate-Binding Cassette Class Transporter (ABC$\mathrm{C} 2$ ), or also known as Multidrug Resistance Protein 2 (MRP2). These transporter are located on luminal/apical hepatocyte membrane, epithelial cells of the small intestine, renal proximal tubule cells, and the luminal surface of the cell endothelial in the brain. These transporters have a fairly strong affinity to methotrexate, so they have important role in methotrexate elimination. The polymorphism in MRP2 is one of genetic factors that may cause variability of pharmacokinetics in patients who received high doses of methotrexate. On the other hand, the overexpression of these transporters may lead to methotrexate resistance. However, in this study, the examination of $\mathrm{ABCC} 2$ gene polymorphism was not performed.

The results of correlation analysis showed that there was negative correlation between the levels of methotrexate in blood and insignificant creatinine clearance. This indicated that if there was an increasing levels of methotrexate in blood, there might be a decrease in creatinine clearance which was not statistically significant. These results were in contrast to a study conducted by Xu et al. in 2014 which showed that the levels of methotrexate in the blood were negatively significant with creatinine clearance at hours 24 and 48 statistically. This may be due to the difference in methotrexate doses used in this study and those in Xu et al.'s, thus the correlation results were different (Xu et al 2014).

According to the discussion above, it is necessary to conduct population pharmacokinetics study related to the use of high dose of methotrexate in pediatric patients with ALL in Indonesia to estimate the parameters of pharmacokinetics of methotrexate individually in pediatric patients with ALL in Indonesia, to reduce the number of blood samples for monitoring the levels of methotrexate in the blood. Further studies are needed on the accuracy of leucovorin dose to prevent side effects due to the use of high doses of methotrexate.

\section{CONCLUSION}

The study results of 14 ALL patients who received high dose of methotrexate $1000 \mathrm{mg} / \mathrm{m}^{2}$ measured at hours 24 and 48 showed that patients' creatinine serum and creatinine clearance after high dose of methotrexate administration were in normal range of $0.09-0.79 \mathrm{mg} / \mathrm{dl}$ and $73.10-598.98 \mathrm{ml} / \mathrm{min} / \mathrm{m}^{2}$. Creatinine serum and creatinine clearance baselines were $0.26-0.56 \mathrm{mg} / \mathrm{dl}$ and $119.78-375.29 \mathrm{ml} / \mathrm{min} / 1.73 \mathrm{~m}^{2}$. The levels in blood after administration of high doses of methotrexate at hour 24 were in the range of $10.77-316.56 \mathrm{ng} / \mathrm{ml}$, while at hour 48 it was in the range of $2.00-231.54 \mathrm{ng} / \mathrm{ml}$ below toxic levels to the kidneys. Thus, the high dose of methotrexate is safely administered to pediatric patients with ALL in Indonesia.

\section{REFERENCES}

Alldredge BK, Corelli RL, Ernst ME, et al (2013). Koda-kimble \& young's applied therapeutics: the clinical use of drugs, 10th Ed. Philadelphia, Lippincott Williams \& Wilkins

Bleyer WA and Dedrick RL (1978). Clinical pharmacology of intrathecal methotrexate i pharmacokinetics in nontoxic patients after lumbar injection. Cancer Treatment Reports Vol 61, 703-8

Borsi JD and Moe PJ (1987). A comparative study on pharmacokinetics of methotrexate in a dose range of $0,5 \mathrm{~g}$ to $33,6 \mathrm{~g} / \mathrm{m}^{2}$ in children with acute lymphoblastic leukemia. Cancer Vol 60, 5-13

Hallworth MJ and Capps NE, 1993. Therapeutic drug monitoring and clinical biochemistry. London, ACB Venture Publications, p 70-73

Hempel L, Misselwitz J, Fleck C, et al (2003). Influence of high dose methotrexate therapy (HD-MTX) on glomerular and tubular kidney function. Medical Pediatric Oncology Vol 40, 348-354

Jacobs SA, Stoller RG, Chabner BA, et al (1976). 7hydroxymethotrexate as a urinary metabolite in human subjects and rhesus monkeys receiving high dose methotrexate. The Journal of Clinical Investigation Vol 57, 534-538

Kliegman RM, Stanton BF, St. Geme JW, et al (2016). Nelson Textbook of Pediatrics, 20th Ed. Philadelphia, Elsevier, p 2437-244

Lennard L (1999). Therapeutic drug monitoring of antimetabolic cytotoxic drug. British Journal of Clinical Pharmacology Vol 47, 131-143

Odoul F, Le Guellec C, Lamagnere JP, et al (1999). Prediction of methotrexate elimination after high dose infusion in children with acute lymphoblastic leukemia using a population pharmacokinetic approach. Fundamental Clinical Pharmacology Vol 13, 595604 
Rau T, Erney B, Gores R, et al (2006). High-dose methotrexate in pediatric acute lymphoblastic leukemia: Impact of $\mathrm{ABCC} 2$ polymorphisms on plasma concentration. Clinical Pharmacology Therapy Vol 80, 468-76

Sahnl V, Choudhury D, Ahmed Z (2009). Chemotherapy-associated renal dysfunction. Nature Reviews Nephrology Vol 6, 450-462
Xu WQ, Zhang LY, Chen XY, et al (2014). Serum creatinine and creatinine clearance for predicting plasma methotrexate concentrations after high-dose methotrexate chemotherapy for the treatment for childhood lymphoblastic malignancies. Cancer Chemotherapy Pharmacology Vol 73, 79-86 